\title{
RADIOCARBON AGE AND GEOCHEMISTRY OF THE INFILLINGS OF SMALL CLOSED DEPRESSIONS FROM WESTERN POLESIE (POLAND SE, UKRAINE NW)
}

\author{
RADOSŁAW DOBROWOLSKI ${ }^{1}$, MARTA ZIÓŁEK ${ }^{1}$, KRYSTYNA BALAGA ${ }^{1}$, \\ JERZY MELKE ${ }^{1}$ and ANDRIJ BOGUCKI ${ }^{2}$ \\ ${ }^{1}$ Institute of Earth Sciences, Maria Curie-Skłodowska University, Kraśnicka 2 cd, PL-20-718 Lublin, Poland \\ ${ }^{2}$ Faculty of Geography, Ivan Franko National University, Lviv, Ukraine Doroshenka 41, UA- 290000 Lviv, Ukraine
}

Received 4 November 2009

Accepted 24 March 2010

\begin{abstract}
In this paper we report the results of interdisciplinary investigations of deposits filling small closed depressions in the Western Polesie region. There were reconstructed the environmental changes and the main evolution phases of four morphometrically similar forms (=research sites) situated in the Lublin and Volhynia parts of the Polesie region. The gathered sedimentological, chronostratigraphical, palynological and geochemical data evidence great lithological (peats, gyttja, calcareous tufa) and age (Late Glacial, Neoholocene) differences between the deposits filling individual forms and indirectly suggest their karstic origin.
\end{abstract}

Keywords: closed depressions, chalk karst, radiocarbon dating, geochemistry, Western Polesie.

\section{INTRODUCTION}

One of the main elements of the Western Polesie relief, that determines its landscape separate character, are small closed depressions filled with mineral-organic or/and organic sediments. On the basis of indirect premises they are generally assigned with karstic (due to the proximity of carbonate substratum) or thermokarstic (on account of the assumed Late Glacial age) origin (e.g. Wilgat, 1954; Maruszczak, 1966; Wojtanowicz, 1994 and Dobrowolski, 1998). Forms of this type were the subject of detailed palaeoenvironmental and chronostratigraphic studies quite rarely.

The attempt was taken to reconstruct the conditions of development of selected small closed depressions from the Western Polesie. It was based on the results of: (1) lithofacial analysis of biogenic sediments, (2) geochemical analysis (content of main micro- and macroelements), (3) radiocarbon dating. The following basic criterions for choosing the sites were assumed: (1) similar morphometric parameters of forms (area, shape and horizontal dimensions), and at the same time different (2) morphological and hypsometric position and (3) different substratum lithology (solid carbonate rocks vs. loose mineral deposits).

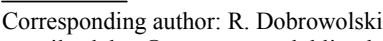

e-mail: rdobro@poczta.umcs.lublin.pl

ISSN 1897-1695 (online), 1733-8387 (print) @ 2010 GADAM Centre, Institute of Physics, Silesian University of Technology.

All rights reserved.

\section{GEOLOGICAL AND GEOMORPHOLOGICAL SETTINGS}

The Western Polesie region, situated in the foreland of the Lublin-Volhynia Uplands is a peripheral, southwestern part of the East European Lowlands. It consists of the Lublin Polesie (in Poland) and the Wolhynia Polesie (in Ukraine and Belarus). Compared with adjacent regions, it is characterized by very monotonous landscape (=dominance of biogenic, limnic and fluvial accumulation plains) with small hypsometric diversity (150-200 m a.s.l., with mean relative heights not exceeding a dozen or so metres). In respect of geology, the whole region is situated within the East-European craton, mostly in its two structural units: Volhynia Elevation in the east and Kumów Elevation in the west (Chiżniakow and Żelichowski, 1974).

Quaternary deposits are predominant on the ground surface. These are mostly Saalian glaciogenic deposits (sands, gravels and till), Vistulian fluvial- and limnicperiglacial sands and silts, and Holocene peat, gyttja, and organic-mineral muds. Usually they directly overlie the Upper Cretaceous carbonate rocks - chalky marls, chalks, limestones. The total thickness of Quaternary deposits is rather small (usually 5-20 m); it considerably increases (in places to over $100 \mathrm{~m}$ ) only within fossil erosion (Buraczyński, 1984 and Zalessky, 1999) and tectonic troughs 
(Harasimiuk and Henkiel, 1979 and Dobrowolski et al., 2004, 2005). The Palaeogene and Neogene deposits (mostly sands and silts) occur as the patches on the Upper Cretaceous rocks in the Volhynia Polesie.

\section{INVESTIGATED SITES}

Four sites were selected for detailed field survey. Three of them (Nowiny, Biesiadki and Antonin) are situated in the western, Polish part of the Western Polesie, and one (Kovel) - in the eastern, Ukrainian part (Fig. 1). Their detailed description, and the scope of carried out research is presented below.

Nowiny (51'11'39”N; 2330'44”E). The site (Fig. 1) is situated within a large Vistulian limnic terrace, occurring at 178-180 $\mathrm{m}$ a.s.l., the surface of which is diversified by many small karst depressions. Their density reaches 50 forms $/ \mathrm{km}^{2}$ (Dobrowolski, 1998). The examined form is an elliptic doline $(100 \times 200 \mathrm{~m})$ with the maximum depth of $1.50 \mathrm{~m}$, which is occupied by forest fen overgrown with alder carr. Surface deposits are represented by a relatively thin (2-5 m) series of the Vistulian limnic sands and silts. They directly overlie the Upper Maastrichtian chalk (Buraczyński and Wojtanowicz, 1986). The organic series filling the form consists of: (1) sedge peat (lower part of the organic series), (2) reed sedge and (3) sedge-wood peat (upper part of the organic series), and (4) detritus-calcareous gyttja (Fig. 2). The core, taken in the central part of the form to the depth of $125 \mathrm{~cm}$, was sampled every $5 \mathrm{~cm}$.

Biesiadki (51 ${ }^{\circ} 16^{\prime} 53^{\prime \prime N}$; 2309'17'E). The site (Fig. 1) is a large (about 4 ha in area, $4 \mathrm{~m}$ in depth) elliptic form of NNW-SSE orientation, without outflow, occupied by sedge fen. It is situated within the Vistulian limnic accumulation terrace (175-185 $\mathrm{m}$ a.s.l., relative heights 5-10 m). The Upper Maastrichtian carbonate deposits (chalk and chalky marls) are commonly exposed or/and occur under a relatively thin (2-3 m) series of silts and silty sands (Rzechowski, 1966). The bottom of the examined form is filled with a series of mineral-organic deposits: (1) silts (=lower part of the series), (2) clayeydetritus gyttjas, (3) sedge peats, (4) moss-sedge peats, and (5) sedge-reed peats (Fig. 3). The core was taken in the central part of the depression to the depth of $365 \mathrm{~cm}$, and divided into 57 samples.

Antonin (51 ${ }^{\circ} 08^{\prime} 23^{\prime}$ N; $23^{\circ} 34^{\prime} 00^{\prime}$ E). The site (Fig. 1) is situated at the foot of an isolated hill (Góra Kredowa $223 \mathrm{~m}$ a.s.1.), on the pediment (187-192 m a.s.l.) developed in the Upper Maastrichtian chalk. The pediment surface, in places covered by a thin (about $1 \mathrm{~m}$ ) series of the Vistulian limnic sands and silts, is diversified by many karst forms - dolines and uvalas (Dobrowolski, 1998). The examined form is a large doline of regular circular shape, 0.3 ha in area and about $5 \mathrm{~m}$ in depth. It is filled with the $2 \mathrm{~m}$ thick series of peat (mainly moss and sedge-moss), interbedded with fine-grained tufa (Fig. 4). The peat-tufa bed is completely drained because it is situated within the zone of influence of depression cone of groundwater intake. $185 \mathrm{~cm}$ long core was taken in the central part of the doline and divided into 43 samples.

Kovel (51'12'45'N; 2440'14”E). The site (Fig. 1) a large circular closed depression (200 $\mathrm{m}$ in diameter, 3.5

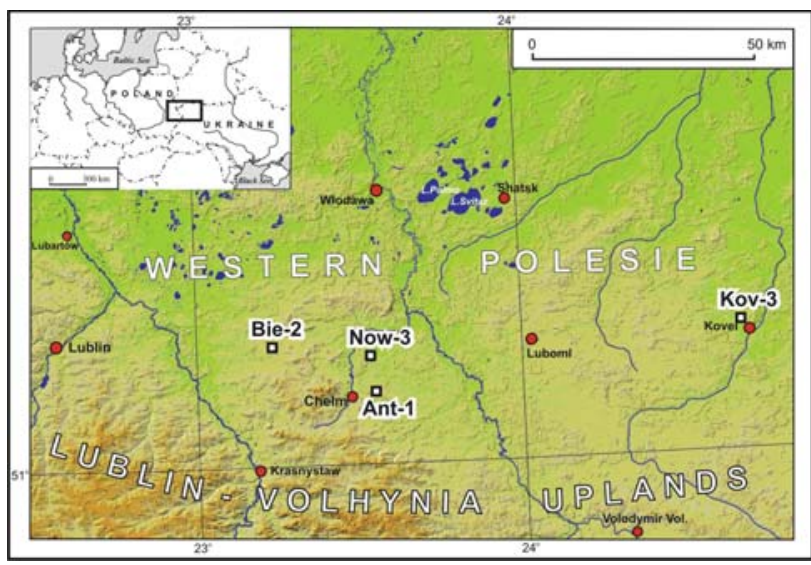

Fig. 1. Location of the studied sites.

$\mathrm{m}$ in depth) - is situated within the Kovel city limits (NW Ukraine). It occurs near the edge of the Turia River valley (right-bank tributary of the Pripyat River), on the pediment (175-180 m a.s.1.) developed in the Santonian chalk (Zalesskij, 1991). The form is filled with: (1) organic clay (lower part of the series), (2) clayey gyttja, (3) detritus gyttja, (4) moss peat, (5) sedge-moss peat, and (6) reed sedge peat (Fig. 5). The core was taken in the centre of the form to the depth of $350 \mathrm{~cm}$, and divided into 35 samples.

\section{METHODS}

\section{Sedimentological analysis}

Detailed geological survey was carried out in each of the examined sites. Core drillings were made, using Eijkelkamp hand auger with peat sampler $5 \mathrm{~cm}$ in diameter, every 10-25 m along geodetically outlined sections. Macroscopic lithofacial analysis of biogenic and mineralbiogenic sediments, taken from the cores with undisturbed structure, was made. The Troels-Smith method was used for the description of deposits (Troels-Smith, 1955).

\section{Geochemical analysis}

Complete geochemical analysis was carried out for 4 peat cores divided into 5 or $10 \mathrm{~cm}$ long sections or according to variability of peat materials. Dry matter, organic matter and ash content were determined by standard methods used in chemical analysis of organic soils (Sapek and Sapek, 1997). Acidity (as pH) was measured from $\mathrm{CaCl}_{2}(0.01 \mathrm{M})$ suspension of peat and the amount of $\mathrm{CaCO}_{3}$ was determined using standard Scheibler method modified by Lityński et al (1976). Macroelements ( $\mathrm{Ca}, \mathrm{Mg}, \mathrm{Na}, \mathrm{K}, \mathrm{Fe}, \mathrm{Al})$ and microelements (Mn, $\mathrm{Cu}, \mathrm{Zn}, \mathrm{Ni}, \mathrm{Pb}, \mathrm{Cd}$ ) were analysed using the AAS method after removal of organic matter and digestion of mineral matter with mixture of hydrofluoric and perchloric acids. Geochemical analyses were carried out based on the reference samples SO-2 and SO-4 from Canada Centre for Mineral and Energy Technology. Precision of geochemical analyses was within the range from about $2 \%$ (e.g. $1.65 \%$ for $\mathrm{Al}$ and $1.97 \%$ for $\mathrm{Fe}$ ) to about $8 \%$ (e.g. $7.40 \%$ for $\mathrm{Mg}$ and $8.75 \%$ for $\mathrm{Ni}$ ). 


\section{Radiocarbon dating}

Chronology of events is based on the radiocarbon dating of bottom deposit series with the highest content of organic matter, which evidences the main cycles of organic sedimentation in the examined depressions. The radiocarbon analysis and the so-called graphic radiocarbon dating method used in Kiev Radiocarbon Laboratory (Kovaliukh and Skripkin, 1994) were carried out for eight samples. One sample from the Kovel profile was dated in the Gliwice Radiocarbon Laboratory. Results of the dating were presented in Table 1 and in the Figs. 2-5.

\section{Pollen analysis}

Samples selected for pollen analysis represent the beginning of biogenic deposition in the examined sites. Samples for microscopic analysis were prepared according to widely accepted standard methods (Wasylikowa, 1973 and Faegri and Iversen, 1989). At least 500 pollen grains of trees and all other sporomorphs were counted under a microscope for each sample. Statistical analyses were made on the basis of the total sum of AP and NAP, without limnophyta, telmatophyta, and spores. The results were presented in the form of cyclograms taking into account only these tree taxa the frequencies of which were at least 1\% (Fig. 6).

\section{RESULTS}

\section{Sedimentological analysis}

The thickness of the bored deposits was from $\sim 1.5 \mathrm{~m}$ (Nowiny site) to $\sim 3.5 \mathrm{~m}$ (Biesiadki and Kovel sites).
Despite morphometric similarity of the studied closed depressions (depth, shape, area, and horizontal dimensions), the fill deposits are distinctly lithofacially differentiated. Depending on the hypsometric position of a form, character of supply, and lithology of substratum, it is filled with different deposits (Figs. 2-5): (1) peat (Biesiadki and Kovel sites), (2) peat and gyttja (Nowiny site) and (3) peat and calcareous tufa (Antonin site). Peat deposits are represented by (1) strongly and moderately decomposed sedge and reed-sedge peat (forming the main part of the bed in most sites), (2) strongly and moderately decomposed sedge-wood and reed-wood peats (usually as thin inserts, except for the Nowiny site where they form the upper part of the bed), (3) slightly decomposed moss and sedge-moss peat (usually in the lower parts of the beds, except for the Antonin site where they occur in the whole profile). Gyttja deposits (maximum thickness of about $30 \mathrm{~cm}$ ) occur only in the lower parts of the profiles; there are mostly detritus and detritus-calcareous gyttja. Calcareous tufa was found only in the Antonin site where they occur as inserts in moss peat. In respect of grains size it was fine-grained tufa. Therefore, accumulation occurred in different environmental conditions (paludic, limnic, and spring), which often changed with time.

\section{Geochemical analysis}

Vertical distribution of macro- and microelements is very closely connected with lithologic types of bottom deposits (lithologic boundary usually corresponds to a distinct geochemical boundary). It concerns especially those elements, which are the main chemical components of the deposits and determine the nature of geochemical

Table 1. Results of radiocarbon dating of biogenic deposits filling the examined small closed depressions (OxCal v. 4.10 with calibration curve IntCal 09, Bronk Ramsey, 2009).

\begin{tabular}{|c|c|c|c|c|c|c|}
\hline \multirow{2}{*}{$\begin{array}{l}\text { Sample } \\
\text { name/Site }\end{array}$} & \multirow{2}{*}{$\begin{array}{l}\text { Depth } \\
\text { (cm) }\end{array}$} & \multirow[b]{2}{*}{ Lithology } & \multirow[b]{2}{*}{ Lab. index } & \multirow{2}{*}{$\begin{array}{l}{ }^{14} \mathrm{C} \text { Age } \\
\text { (BP) }\end{array}$} & \multicolumn{2}{|c|}{ Range of Cal. Age (AD/BC) } \\
\hline & & & & & $68.2 \%$ probability $(1 \sigma)$ & $95.4 \%$ probability $(2 \sigma)$ \\
\hline & & & & & $378 \mathrm{BC}(63.0 \%) 156 \mathrm{BC}$ & 409BC (95.0\%) 28AD \\
\hline Antonin 1 & $49-52$ & moss peat & Ki - 11387 & $2180 \pm 100$ & $136 \mathrm{BC}(5.2 \%) 114 \mathrm{BC}$ & $40 A D(0.4 \%) 49 A D$ \\
\hline Antonin 2 & $95-100$ & moss peat & Ki - 11388 & $2920 \pm 80$ & $\begin{array}{c}\text { 1258BC }(7.0 \%) 1230 \mathrm{BC} 1219 \mathrm{BC} \\
(61.2 \%) 1010 \mathrm{BC}\end{array}$ & $\begin{array}{c}\text { 1377BC (3.3\%) 1338BC 1321BC } \\
(92.1 \%) 916 \mathrm{BC}\end{array}$ \\
\hline & & sedge-reed & & & 1118AD (43.5\%) 1220AD & \\
\hline Biesiadki 1 & $25-30$ & peat & Ki - 11389 & $880 \pm 80$ & 1044AD (24.7\%) 1104AD & 1020AD (95.4\%) 1272AD \\
\hline Biesiadki 2 & $220-230$ & sedge peat & $\mathrm{Ki}-11390$ & $3570 \pm 100$ & $2035 \mathrm{BC}(68.2 \%) 1756 \mathrm{BC}$ & $2201 \mathrm{BC}(95.4 \%)$ 1667BC \\
\hline Nowiny 1 & 54-57 & $\begin{array}{l}\text { reed-wood } \\
\text { peat }\end{array}$ & Ki - 11385 & $2550 \pm 60$ & $\begin{array}{l}\text { 800BC }(24.8 \%) 746 \mathrm{BC} \\
688 \mathrm{BC}(10.4 \%) 664 \mathrm{BC} \\
646 \mathrm{BC}(32.9 \%) 552 \mathrm{BC}\end{array}$ & $\begin{array}{l}\text { 817BC }(93.0 \%) 506 \mathrm{BC} \\
462 \mathrm{BC}(0.7 \%) 450 \mathrm{BC} \\
440 \mathrm{BC}(1.7 \%) 418 \mathrm{BC}\end{array}$ \\
\hline Nowiny 2 & $95-100$ & sedge peat & Ki - 11386 & $4225 \pm 120$ & $\begin{array}{l}3002 \mathrm{BC}(1.2 \%) 2993 \mathrm{BC} \\
2928 \mathrm{BC}(65.5 \%) 2620 \mathrm{BC} \\
2606 \mathrm{BC}(0.9 \%) 2600 \mathrm{BC} \\
2592 \mathrm{BC}(0.7 \%) 2588 \mathrm{BC}\end{array}$ & $\begin{array}{c}3315 \mathrm{BC}(1.1 \%) 3274 \mathrm{BC} \\
3266 \mathrm{BC}(1.1 \%) 3238 \mathrm{BC} \\
3168 \mathrm{BC}(0.1 \%) 3164 \mathrm{BC} \\
3109 \mathrm{BC}(93.2 \%) 2474 \mathrm{BC}\end{array}$ \\
\hline Kovel 1 & $175-180$ & $\begin{array}{l}\text { reed-wood } \\
\text { peat }\end{array}$ & $\mathrm{Ki}-11384$ & $8570 \pm 150$ & $\begin{array}{l}7936 \mathrm{BC}(0.8 \%) 7928 \mathrm{BC} \\
7914 \mathrm{BC}(1.2 \%) 7900 \mathrm{BC} \\
7834 \mathrm{BC}(66.2 \%) 7468 \mathrm{BC}\end{array}$ & $\begin{array}{l}\text { 8204BC }(6.1 \%) 8036 \mathrm{BC} \\
8014 \mathrm{BC}(89.3 \%) 7310 \mathrm{BC}\end{array}$ \\
\hline Kovel 2 & $235-240$ & moss peat & Ki - 11383 & $9070 \pm 120$ & $\begin{array}{l}8532 \mathrm{BC}(1.8 \%) 8517 \mathrm{BC} \\
8478 \mathrm{BC}(59.0 \%) 8199 \mathrm{BC} \\
8110 \mathrm{BC}(2.1 \%) 8093 \mathrm{BC} \\
8072 \mathrm{BC}(0.6 \%) 8066 \mathrm{BC} \\
8040 \mathrm{BC}(4.7 \%) 8004 \mathrm{BC}\end{array}$ & $\begin{array}{l}8622 \mathrm{BC}(94.5 \%) 7938 \mathrm{BC} \\
7924 \mathrm{BC}(0.1 \%) 7919 \mathrm{BC} \\
7896 \mathrm{BC}(0.7 \%) 7870 \mathrm{BC} \\
7853 \mathrm{BC}(0.1 \%) 7849 \mathrm{BC}\end{array}$ \\
\hline Kovel 3 & $296-306$ & moss peat & Gd - 14082 & $12850 \pm 390$ & $\begin{array}{l}14411 \mathrm{BC}(65.7 \%) 12866 \mathrm{BC} \\
12780 \mathrm{BC}(2.5 \%) 12707 \mathrm{BC}\end{array}$ & 14784BC(95.4\%)12138BC \\
\hline
\end{tabular}




\section{Now-3}
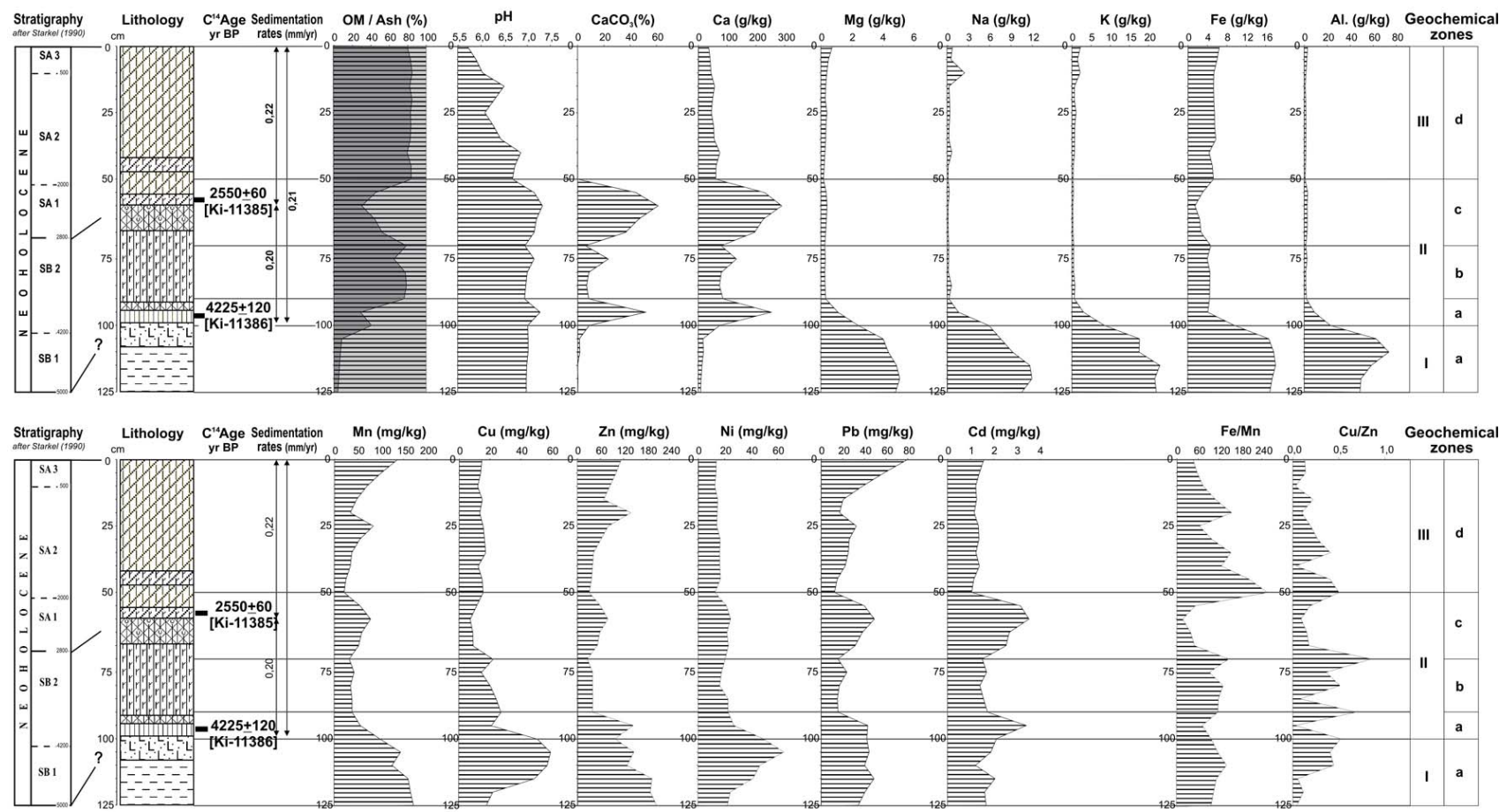

《VXX

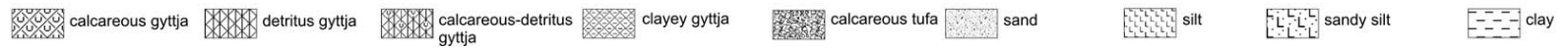

Fig. 2. Lithostratigraphy and geochemistry of the infilling deposits of the investigated small closed depression in the Nowiny site (Now-3 core).

\section{Bie-2}
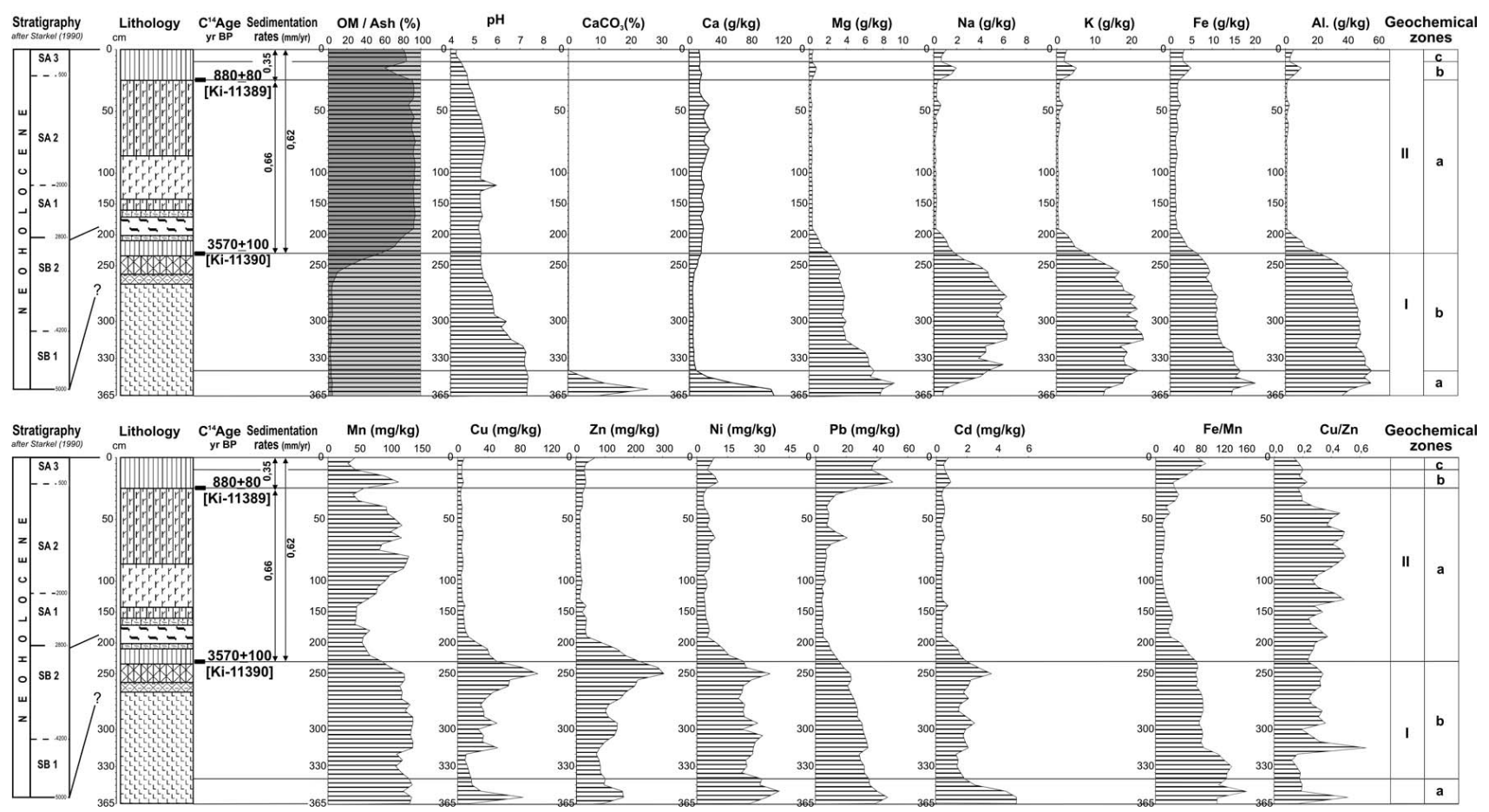

Fig. 3. Lithostratigraphy and geochemistry of the infilling deposits of the investigated small closed depression in the Biesiadki site (Bie-2 core). 


\section{Ant-1}
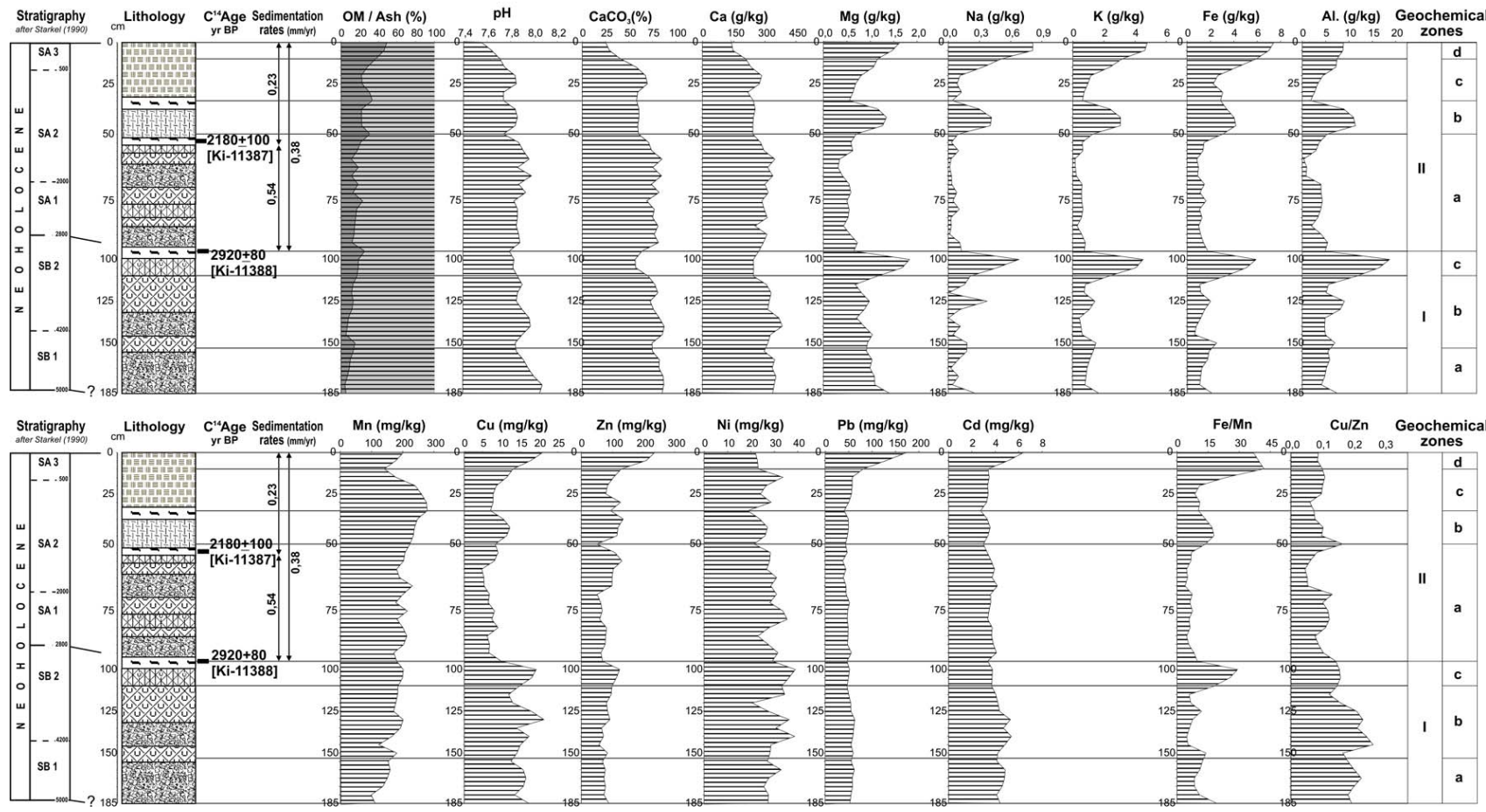

Fig. 4. Lithostratigraphy and geochemistry of the infilling deposits of the investigated small closed depression in the Antonin site (Ant-1 core).

\section{Kov-3}
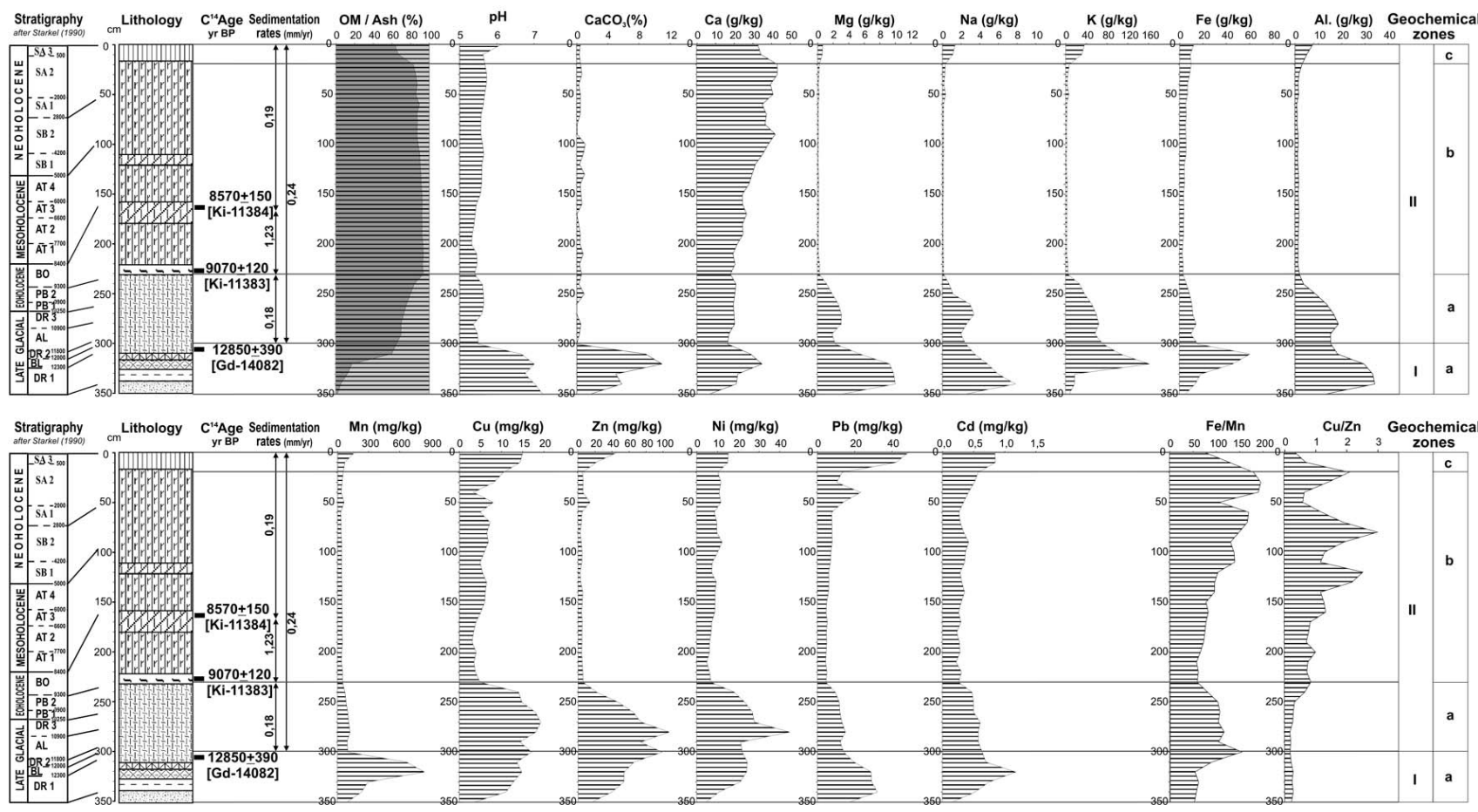

Fig. 5. Lithostratigraphy and geochemistry of the infilling deposits of the investigated small closed depression in the Kovel site (Kov-3 core). 
environment in the studied profile, i.e. $\mathrm{Mg}, \mathrm{Na}, \mathrm{K}, \mathrm{Fe}, \mathrm{Al}$ and $\mathrm{Ca}$ (in the Nowiny profile $\mathrm{Ca}, \mathrm{Fe}, \mathrm{K}, \mathrm{Mg}$ only). On the basis of the relation between the contents of individual elements, two or three main geochemical zones and four to seven minor geochemical subzones can be distinguished in each profile (Figs. 2-5).

Very high content of calcium carbonate is a distinctive feature of the deposits filling the closed depressions in the Antonin (core Ant-1) and Nowiny (core Now-3) sites (Figs. 2 and 4). In the profile Ant-1 it concerns the whole deposit series, and in the profile Now-3 - only the bottom part of the biogenic series (geochemical zone II ac; Figs. 2 and 4). In two other sites (cores Bie-2 and Kov-3) carbonates occur in trace quantities and only in the bottom part of the cores (Figs. 3 and 5). Such a distribution should be directly related to the differences in the depth of occurrence of carbonate substratum or/and lithology of mineral deposits directly underlying peat beds.

The maximum contents of $\mathrm{Mg}, \mathrm{Na}, \mathrm{K}, \mathrm{Fe}, \mathrm{Al}$ are found mainly in the bottom part of the cores - within the mineral deposit series underlying organic series (=geochemical zone I; Figs. 2-5). Vertical distribution of these elements in most sites (except for the Antonin site) reveals a distinct relationship between the contents of them and the ash content. Upwards the profiles, with the rise in the content of organic material, the contents of these elements strongly decrease. Such regularity is rather obvious and results from lithologic differences conditioning different properties of deposit (Shotyk, 1988). The increased contents of these elements in the upper (organic) parts of the cores should be probably related to periodic supply of clastic deposits to sedimentation basin (surface flows) as well as geo- and biochemical processes occurring in the basin. High content of allogenic silicate minerals (i.e. containing $\mathrm{Mg}, \mathrm{K}, \mathrm{Al}, \mathrm{Zn}$ ) in the lower parts of the cores in most sites (except for the Antonin site) confirms the predominant role of slope processes in the first phase of filling the depressions (Willis et al. 1995).

Geochemical record obtained in the Antonin site (core Ant-1) is different from the rest. Distribution of most elements does not reveal relation to ash content. The highest contents of most elements are found within the moss peat inserts. The maximum concentrations of macro- and microelements occur in the upper, strongly decomposed part of the organic series (geochemical zone II d; Fig. 4). This fact results from strong mineralization of organic matter caused by dehydration of deposit (Sapek et al., 1991). The maximum contents of heavy metals $(\mathrm{Cu}, \mathrm{Zn}, \mathrm{Pb}, \mathrm{Cd})$, found in the upper part of the Antonin profile, probably evidence intensive anthropopression (Perkins et al., 2000 and Ziółek and Melke, 2005).

$\mathrm{Mn}$ and $\mathrm{Zn}$ are predominant microelements in the deposits of the examined sites. The highest contents of microelements $(\mathrm{Cu}, \mathrm{Zn}, \mathrm{Ni}, \mathrm{Cd})$ are found in clayeydetritus gyttja underlying the bottom peat in the Biesiadki site (Fig. 3). Analysis of vertical distribution of the $\mathrm{Fe} / \mathrm{Mn}$ and $\mathrm{Cu} / \mathrm{Zn}$ ratios in the deposits of closed depressions can be indicator of environmental changes of reduction-oxidation conditions (Borówka RK, 1992; Digerfeldt, 1988; Willis et al,. 1995 and Wojciechowski, 2000). High values of both indicators are found in the profile Kov-3 (maximum along the section 20-130 cm). The highest value of the $\mathrm{Fe} / \mathrm{Mn}$ indicator is found in the profile Now-3 at the depth of $50 \mathrm{~cm}$. The higher values of redox indicators generally evidence the lowering of water level in depression and accumulation of deposits in reduction conditions (Wojciechowski, 2000). The relatively lowest values of the $\mathrm{Fe} / \mathrm{Mn}$ and $\mathrm{Cu} / \mathrm{Zn}$ ratios are found in the Antonin site. They indicate that deposits were accumulated in more oxidizing conditions, probably connected with ascending water supply to the bed. In this site the low values of redox indicators are accompanied by high content of $\mathrm{CaCO}_{3}$. Similar situation occurs in the Nowiny profile where the sections with high content of $\mathrm{CaCO}_{3}$ are characterized by low values of the $\mathrm{Fe} / \mathrm{Mn}$ and $\mathrm{Cu} / \mathrm{Zn}$ ratios.

\section{Radiocarbon dating}

In the light of radiocarbon dating, biogenic sedimentation in the examined forms started in the Late Glacial (Kovel site) or in the Subboreal period (Biesiadki, Nowiny, and Antonin sites). Mean rate of biogenic sedimentation was determined in particular cores based on radiocarbon dates. It fluctuates from low values, about 0.2 $\mathrm{mm} / \mathrm{yr}$ in the Nowiny and Kovel sites, to relatively high ones, about $0.6 \mathrm{~mm} / \mathrm{yr}$ in the Biesiadki site (vide Figs. 25). The results of radiocarbon dating of biogenic deposits from the examined sites are presented in Table 1.

\section{Pollen analysis}

In the sample from the Nowiny site the percentage of tree pollen exceeds $82 \%$ (Fig. 3). Pinus (25.5\%) and Betula $(20.4 \%)$ are predominant species. The pollen frequencies of Quercus (13.3\%) and Alnus (12.2\%) are rather high, while the values Ulmus (3.1\%), Tilia (1.7\%) and Carpinus $(0.7 \%)$ are considerably lower. The pollen sum of other tree taxa is $1.4 \%$. Corylus reaches $7.4 \%$. Poaceae, Cyperaceae, Artemisia and spores of Polypodiaceae definitely predominate in NAP sum. The relatively high frequency of NAP, and the occurrence of other heliophilous taxa (Asteroidaceae, Cichoridaceae and Prunella) can evidence forest clearings. With reference to the diagrams from the Lublin Polesie region (e.g. Bałaga, $1991,2004,2007)$ the low values of Carpinus $(0.5 \%)$ and lack of Fagus pollen suggest the early phase of the Subboreal period.

In the Besiadki site the AP sum is $81.2 \%$, and in it the pollen values of Betula (20.7\%) and Pinus (25.4\%) are similar to those recorded in the Nowiny site. Pollen percentages of other trees are also similar, except for Carpinus (1.2\%) and Fagus (0.5\%). Poaceae are predominant in NAP sum, and heliophilous taxa are also frequent. Therefore, in comparison with the Nowiny site, it can be supposed that this pollen spectrum represents a slightly younger phase of the Subboreal period, and evidences a gradual spread of hornbeam and the appearance of beech.

In the sample from the Antonin site (Fig. 6) the NAP sum reaches $25.7 \%$, and in it the Cerealia frequency is $1.8 \%$. Taxonomic differentiation is also distinct in this site. The high value of Pinus (about 34\%), and low percentage of Carpinus $(0.4 \%)$ can indicate a phase of intensified human activities when forest cover became 

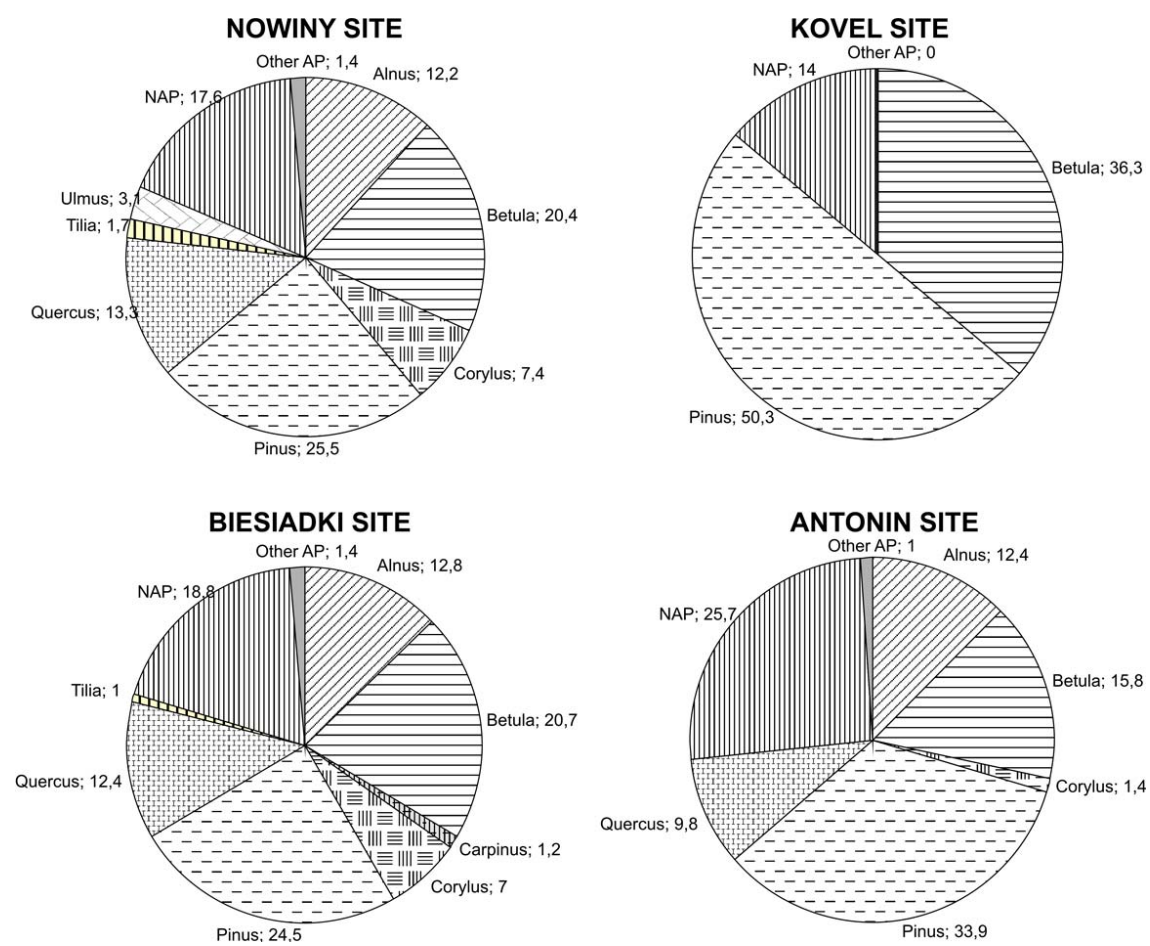

Fig. 6. Percentages of pollen of the selected taxa in the bottom samples of the examined cores.

thinned, and communities with hornbeam were reduced. Better light conditions contributed to more intensive production of pine pollen. Therefore, this pollen spectrum probably represents still younger phase of post-Atlantic development of vegetation cover in comparison with the sites described above.

In the Kovel site (Fig. 6) the AP sum consists of Betula (36.3\%) and Pinus (50.3\%) pollen. NAP sum is predominated by Artemisia 5.2\%, Poaceae $2.9 \%$ and Cypraceae (2.9\%). High pollen values of Nymphaea alba and the occurrence of Typha latifolia and Myriophyllum vericillatum indicate a warm phase of Late Glacial.

\section{DISCUSSION AND FINAL REMARKS}

Small closed depressions, with relatively shallow occurrence of solid carbonate substratum, are common element of the Western Polesie landscape. The collected documentation material indicates that despite their morphometric similarity (horizontal dimensions and depth), they are of various ages (Late Vistulian or Atlanticum/Subboreal), lithology of filling deposits is very diversified, and thickness of lower mineral series is different. The thickness of clastic deposits overlying the Upper Cretaceous rocks in small closed depressions varies from a dozen or so centimetres (Antonin site) to about three metres (Kovel site). These differences have a rather strong effect on the percentage contents of individual macro- and microelements in vertical profiles of the filling deposits, especially in their lower sections. The content of calcium carbonate in the bottom part of biogenic series is relatively high (and decreasing upwards), where the underlying series of clastic deposits is relatively thin (=shallow occurrence of carbonate substratum). Thus, the deposit core from the site Ant-1 is unique as the content of $\mathrm{CaCO}_{3}$ is very high (over $50 \%$ ) in the whole profile. This fact results probably from a unique nature of water supply (evidenced during field investigations) to this form, i.e. ascending supply with water rich in calcium compounds. This supply is sedimentologically recorded as tufa inserts in peat series. In the Nowiny site, despite relatively thin underlying series occurring as silts, there is no direct connection of the chemical composition of bottom biogenic deposits with carbonate substratum rocks. Silts form distinct hydrodynamic barrier for groundwater. The depression was probably supplied with descending water during the whole stage of biogenic aggradation. The increased content of calcium carbonate in the upper part of the profile can be related to high level of groundwater, functioning of paralake reservoirs, and the resulting decalcification of water by macrophytes (Rzepecki, 1985). While lithofacial differences between the deposits filling individual depressions can be explained by regional diversity of deposition and different nature of water supply, the different ages of the forms (= beginning of biogenic sedentation) limit the possibilities of discussion on their origin. Till now the formation of such forms has been usually related to the development of karst (e.g. Rühle, 1935; Wilgat, 1950, 1991; Maruszczak, 1966; Zaleski, 2002 and Dobrowolski, 2006 or thermokarst processes (e.g. Voznachuk, 1973 and Wojtanowcz, 1994), but the turn of Late Vistulian and Holocene has been rather unanimously considered as the time when they were formed. From among the examined sites, this age was determined only for the Kovel site. Pollen and radiocarbon data obtained for other forms exclude their thermokarst origin and indirectly indicate that karst processes in the Western Polesie region could develop in different phases of Upper Quaternary. Therefore, in most (probably all) examined sites there occur forms of reproduced 
karst developed in mineral (fluvioglacial, fluvialperiglacial) deposits of different thickness, which overlie the Upper Cretaceous carbonate rocks.

\section{REFERENCES}

Bałaga K, 1991. The development of Lake Łukcze and changes in plant cover of the south-western part of the Łęczna-Włodawa Lake District in the last 13000 years. Acta Palaeobotanica 30(1,2): 77-146.

Bałaga K, 2004. Changes of vegetation in Lake Perespilno environs (Lublin Polesie) in the Late Glacial and Holocene. Acta Palaeobotanica 44(2): 147-166.

Bałaga K, 2007. Changes in the natural environment recorded in the sediments of Karaśne lake-mire complex (Lublin Polesie, E Poland). Geochronometria 29: 1-21, DOI 10.2478/v10003-007-0032-z.

Borówka RK, 1992. Przebieg i rozmiary denudacji w obrębie śródwysoczyznowych basenów sedymentacyjnych podczas późnego vistulianu i holocenu (The pattern and magnitude of denudation in interplateau sedimentary basins during the Late Vistulian and Holocene). Wydawnictwa Naukowe UAM, Poznań. Seria Geografia 54: 177pp (in Polish).

Bronk Ramsey C, 2009. Bayesian analysis of radiocarbon dates. Radiocarbon 51(1): 337-360.

Buraczyński J, 1984. Rzeźba powierzchni podczwartorzędowej Lubelskiego Zagłẹbia Weglowego (Relief of the sub-Quaternary surface in the Lublin Coal Basin). Annales UMCS, Sect. B, 39: 39-50 (in Polish).

Buraczyński J and Wojtanowicz J, 1986. Szczegółowa Mapa Geologiczna Polski, 1:50 000, ark. Świerże, Okopy (Detailed Geological Map of Poland, 1:50 000, Świerże, Okopy sheets). Warszawa, Wydawnictwa Geologiczne.

Chiżniakow AW and Żelichowski AM, 1974. Zarys tektoniki obszaru lubelsko-lwowskiego (An outline tectonics of the Lublin-Lvov area). Geological Quarterly 18(4): 707-719 (in Polish).

Digerfeldt G, 1988. Reconstruction and regional correlation of Holocene lake-level fluctuations in Lake Bysjön, South Sweden. Boreas $17(2)$ : 165-182.

Dobrowolski R, 1998. Strukturalne uwarunkowania rozwoju współczesnej rzéby krasowej na międzyrzeczu środkowego Wieprza i Bugu (Structural conditions of recent karst relief development in the middle Wieprz and Bug interfluve). Lublin, Wydawnictwo UMCS: 88 pp (in Polish).

Dobrowolski R, 2006. Glacjalna i peryglacjalna transformacja rzeźby krasowej pótnocnego przedpola wyżyn lubelsko-wotyńskich (Polska SE, Ukraina NW) (Glacial and periglacial transformation of karst relief in the northern foreland of the Lublin-Volhynia uplands (SE Poland, NW Ukraine). Lublin, Wydawnictwo UMCS: 184 pp (in Polish).

Dobrowolski R, Terpiłowski S and Zaleski I, 2004. Paleomorfologia podczwartorzedowa zachodniego Polesia i jej wpływ na przebieg odrzańskich (=dnieprzańskich) procesów glacigenicznych (SubQuaternary palaeomorphology of the western Polesie and its influence on the course of the Odranian (=Dnieperian) glaciogenic processes). In: Michalczyk Z, ed, Badania geograficzne $w$ poznawaniu środowiska. Lublin, Wydawnictwo UMCS: 118-122 (in Polish).

Dobrowolski R, Terpiłowski S and Zaleski I, 2005. Rzeźba podplejstoceńska Polesia Wołyńskiego (Sub-Pleistocene relief of the Volhynia Polesie). In: Boguckij A, ed, Glacjat i peryglacjat Polesia Wotyńskiego. Lviv, Centrum Wydawnictw Narodowych Uniwersytetu im. I. Franko: 38-45 (in Polish).

Faegri K and Iversen J, 1989. Textbook of pollen analysis. III ed. Munksgaard, Copenhagen, Denmark: 295 pp.

Harasimiuk M and Henkiel A, 1979. Neogeńskie rowy tektoniczne w okolicy Chełma (Neogene tectonic troughs near Chełm). Przegląd Geologiczny 2: 102-103 (in Polish).

Kovaliukh NN and Skripkin VV, 1994. An universal technology for oxidation of carbon-containing materials for radiocarbon dating, Abstract and Papers of Conference on Geochronology and Dendrochronology of Old Town and Radiocarbon Dating of Archaeological Findings, Oct. 31-Nov. 4, Lithuania, Vilnius, Vilnius University Press, Vilnius: $37-42 \mathrm{pp}$.

Lityński T, Jurkowska H and Gorlach E, 1976. Analiza chemiczno-rolnicza. (Chemical-agriculture analysis). Warszawa, PWN: 330 pp (in Polish).

Maruszczak H, 1966. Zjawiska krasowe w skałach górnokredowych międzyrzecza Wisły i Bugu (Typ krasu kredy piszącej) (Karst phenomena in the Upper Cretaceous rocks of the Vistula and Bug interfluve (Chalk karst type). Przeglad Geograficzny 38(3): 339370 (in Polish).

Perkins S M, Filippelli GM and Souch CJ, 2000. Airborne trace metal contamination of wetland sediments at Indiana Dunes National Lakeshore. Water, Air, Soil Pollution 122: 231-260, DOI 10.1023/A:1005254916966.

Rühle E, 1935. Jeziora krasowe zachodniej cześci Polesia Wołyńskiego (Karst lakes in the western part of the Volhynia Polesie). Rocznik Wotyński 4: 210-241.

Rzechowski J, 1966. Mapa geologiczna Polski. Mapa utworów powierzchniowych. 1:200 000, arkusz Chełm, Horodło (Geological Map of Poland. Map of surface deposits. 1:200 000, Chełm, Horodło sheets). Warszawa, PIG.

Rzepecki P, 1985. Lacustrine calcareous sediments of Northern Poland between Łyna and Brda. Zeszyty Naukowe AGH 11: 5-78 (in Polish with English summary).

Sapek A and Sapek B, 1997. Metody analizy chemicznej gleb organicznych (Methods of chemical analysis of organic soils). In: Okruszko H, ed., Materiaty instruktażowe 115. Instytut Melioracji i Użytków Zielonych, Falenty: 1-80 (in Polish).

Sapek A, Sapek B and Gotkiewicz J, 1991. Różnicowanie się składu chemicznego warstwy murszowej gleby torfowej (Diversity of chemical composition of muck layer of peat soil). Wiadomości IMUZ 16(3): 109-131 (in Polish).

Shotyk W, 1988. Review of the Inorganic Geochemistry of Peats and Peatland Waters. Earth-Science Reviews 25: 95-176, DOI 10.1016/0012-8252(88)90067-0.

Starkel L, 1990. Stratygrafia holocenu jako interglacjału (Stratigraphy of Holocene as interglacial). Przeglad Geologiczny 38(1): 13-15 (in Polish).

Troels-Smith J, 1955. Karakterisering af lose jordarter (Characterization of unconsolidated sediments). Danmark Geologiske Undersøgelse 4, 3(10): 39-73 (in Danish).

Voznachuk LN, 1973. K stratigrafii i paleogeografii neoplejstocena Belorussi i smiezhnych territorii (About stratigraphy and palaeogeography of Belarus and adjacent areas). Problemy paleogeografii Belorussi, Minsk: 45-75 (in Russian).

Wasylikowa K. 1973. Badania kopalnych szczątków roślin wyższych (Investigations of fossil remains of higher plants). In: Rühle E, ed, Metodyka badań osadów czwartorzędowych, Warszawa, Wydawnictwa Geologiczne: 161-210 (in Polish).

Willis KJ, Sümegi P, Braun M and Tŏth A, 1995. The late Quaternary environmental history of Batorliget, N.E. Hungary. Palaeogeography, Palaeoclimatology, Palaeoecology 118(1-2): 25-47, DOI 10.1016/0031-0182(95)00004-6.

Wilgat T, 1950. Kras okolic Cycowa (Karst near Cyców). Annales UMCS, Sect. B, 4: 229-256 (in Polish).

Wilgat $\mathrm{T}, 1954$. Jeziora Łęczyńsko-Włodawskie (ŁęczyńskoWłodawskie Lakes). Annales UMCS, Sect.B, 8: 37-122 (in Polish).

Wilgat T, 1991. Geneza jezior (Origin of lakes). In: Wybrane zagadnienia wartości i zagrożeń środowiska przyrodniczego jezior Piaseczno i Głębokie na Pojezierzu Łęczyńsko-Włodawskim. Studia Ośrodka Dokumentacji Fizjograficznej PAN 9: 112-120 (in Polish).

Wojtanowicz J, 1994. O termokrasowej genezie jezior łęczyńskowłodawskich (About thermokarst origin of the Łęczna-Włodawa lakes). Annales UMCS, Sect. B, 49: 1-18 (in Polish).

Wojciechowski A, 2000. Zmiany paleohydrologiczne $w$ środkowej Wielkopolsce $w$ ciagu ostatnich 12000 lat $w$ świetle badań osadów jeziornych rynny kórnicko-zaniemyskiej (Palaeohydrological changes In the central Wielkopolska Lowland during the last 12,000 years on the basis of deposits of the Kórnik-Zaniemyśl lasek). Poznań, Wydawnictwa Naukowe UAM, Seria Geografia nr 63: 1-236 (in Polish).

Zaleski I, 2002. Regarding the origin of lakes in the area of Volhynian Polesiye. Limnological Review 2: 453-455.

Zalesskij I, 1991. Geologichna karta Volynskoj oblasti (Geological map of the Volhynia District). In: Burchak N W, ed., Atlas Volynskoj oblasti. Moskva, Komitet Geodezji i Kartografii SRSR: 4 (in Russian).

Zalessky I, 1999. Morfogenetyczne osobliwości rzeźby podłoża plejstocenu na Polesiu Wołyńskim (Morphogenetic features of the Pleistocene substratum relief in the Volhynia Polesie). Annales UMCS, Sect. B, 54, 2: 33-40 (in Polish)

Ziółek M and Melke J, 2005. Heavy metals content in soil developed from peat exposed to varying degrees of anthropopressure. In: Zgłobicki W and Rejman J, eds., Human impact on sensitive geosystems. Lublin, Wydawnictwo UMCS: 157-165. 